\title{
Устранение недобросовестных практик при закупке радиоэлектронной продукции гражданского назначения
}

\author{
По материалам Экспертного Совета по развитию электронной \\ и радиоэлектронной промышленности при Комитете ГД РФ \\ по экономической политике, промышленности, инновационному \\ развитию и предпринимательству и Координационного совета \\ Союза машиностроителей России
}

А. Брыкин, д. э. н. ${ }^{1}$

Развитие отечественной электронной и радиоэлектронной промышленности является критически важной задачей при переходе экономики и общественных отношениях к цифровым моделям. Анализ существующих практик регулирования, формирования рынков сбыта и механизмов защиты отечественных производителей указывает на наличие системных проблем в этой сфере. В статье рассматриваются проблемы и даются предложения, способные изменить сложившиеся практики госзакупок, идущие в разрез с планами по диверсификации и развитию российской радиоэлектронной отрасли.

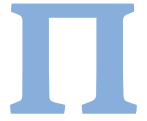

редприятия российской радиоэлектронной промышленности являются ключевым звеном при переходе Российской Федерации от сырьевой к цифровой экономике: они вовлечены в реализацию программ импортозамещения, мероприятий ФЦП и госпрограмм, реализуя отраслевые и корпоративные стратегии в соответствии с майскими Указами Президента РФ. В отрасли решаются ключевые задачи по диверсификации предприятий ОПК, привлекаются инвестиции в перспективные проекты по производству конкурентоспособной гражданской продукции.

Радиоэлектронный комплекс ГК «Ростех» (РЭК) состоит из 368 предприятий, среди которых в терминах стратегии отраслевого развития имеются как центры технологических компетенций, так и организации - отраслевые чемпионы. Комплекс является своеобразным зеркалом, которое отражает как положительные, так и негативные эффекты от принимаемых на государственном уровне решений, характеризуя

Председатель Координационного совета разработчиков и производителей радиоэлектронной аппаратуры, электронной компонентной базы и продукции машиностроения Союза машиностроителей России (КС), профессор Финансового университета при Правительстве Российской Федерации. состояние дел в отрасли. Поэтому в данной статье будут рассмотрены практики именно этого системообразующего сегмента отечественной радиоэлектронной промышленности.

В 2018 году объем производства гражданской продукции РЭК вырос на 60\% и составил в абсолютных цифрах 66 млрд руб. Доля гражданской продукции в выручке за год увеличилась на 6,3\% и составила 23,2\%. Рост доли гражданской продукции обусловлен в первую очередь значительным научно-производственным потенциалом комплекса. Однако размер доли РЭК в общем объеме рынка свидетельствует о существенных резервах для российских предприятий.

В 1990-е годы распался СССР и рынок был безропотно отдан иностранным компаниям. Отечественные производства, которые работали в строгой кооперационной иерархии, остались за его бортом. И это была не конкуренция, а экономическая агрессия со стороны отдельных иностранных государств, чьи компании и сегодня продолжают доминировать на отечественном рынке, выкачивая значительную часть российского государственного бюджета и бюджета компаний с госучастием

Стратегией развития электронной промышленности определены три этапа освоения сегментов коммерческого рынка: 
- традиционные рынки до 2020 года (телекоммуникационное оборудование и вычислительная техника, системы хранения данных, АСУ, автомобильная электроника и др.);

- новые рынки с 2021 года (интеллектуальная энергетика, телемедицина, беспилотная авиация, Интернет вещей, 5G);

- рынки будущего с 2025 года (робототехника, искусственный интеллект, все виды беспилотного транспорта, нейротехнологии, квантовые вычисления и др.).

Очевидно, что выход на новые рынки, а тем более на рынки будущего, возможен только при завоевании нами твердых позиций на традиционных внутренних рынках. От эффективности на гражданских рынках приборных предприятий напрямую зависит спрос на изделия отечественной ЭКБ. Поэтому решение нормативно-правовых вопросов, связанных с практиками, выявленными на рынках сбыта, является важнейшим для отрасли.

Анализ внутреннего радиоэлектронного рынка страны наглядно показывает доминирование иностранной продукции в традиционных гражданских сегментах по различным категориям заказчиков.

В 2018 году выручка Радиоэлектронного комплекса Ростеха на рынке ФОИВ составила 18 млрд руб. Вместе с тем объем закупок ФОИВ только в части телекоммуникационного оборудования и вычислительной техники составляет не менее 100 млрд руб. в год. Аналогичная картина видна и при закупках естественных монополий, объем закупок которых в сегменте радиоэлектроники, по оценкам экспертов КС, составляет около 2 трлн руб. в год. Известно, что большая часть закупок подобных компаний выводится за рамки 223-Ф3, однако и сегмент закупок в рамках этого закона со стороны крупных компаний с госучастием весьма велик. Здесь контрактация РЭК составила 6,5 млрд руб. в 2018 году, причем ее основная доля в размере 6 млрд руб. была получена в результате успешного стратегического партнерства с Россетями.

Общий объем закупок только Россетей в сегменте радиоэлектроники в 2018 году составил 245 млрд руб., а предприятия РЭК смогли поучаствовать в конкурсах только на 19 млрд руб. В закупках на 100 млрд руб. не смогли принять участие из-за системных проблем, характерных для большинства крупных заказчиков в силу стереотипов и несовершенства правовых норм, которые фактически не обеспечивают приоритет отечественной продукции.

Даже готовые конкурентоспособные по цене и качеству продукты вывести на рынок не всегда представляется возможным, так как Федеральные органы исполнительной власти недостаточно стимулируют спрос на отечественную продукцию, а в ряде случаях необоснованно затягивают принятие важных решений.
Например, в марте 2018 года в РЭК создана конкурентоспособная система хранения данных «Купол» (СХД), качество которой подтверждено НТС ФСБ и Минкомсвязью России. Степень локализации сегодня - 65\%. Однако, в рамках реализации "Закона Яровой» Минкомсвязи целый год не вносило предложенные отраслью изменения в Постановление Правительства РФ № 445 об обязательном применении отечественного оборудования для построения СХД.

Согласно исследованию компании ADC, в 2018 году отечественный рынок СХД составил 409 млн долл. Из 15 вендоров лишь один российский, доля которого на рынке составила 38\% с выручкой 34 млн долл. Выручка же китайской компании Huawei с долей в 7\% составила 65 млн долл. При объеме поставок в денежном выражении в пять раз меньше, чем у отечественного производителя, доля рынка китайского производителя в два раза превышает нашу. При наличии отечественной конкурентоспособной продукции госзаказчики приобрели иностранные СХД по более высокой цене, а российские производители недополучили более 15 млрд руб.

Рассмотрим более подробно системные проблемы при закупках радиоэлектронной продукции гражданского назначения.

1. Такие механизмы импортозамещения как "запреты", "третий лишний" и "ценовые преференции" легко обходятся заказчиками и слабо работают на стимулирование закупок российских товаров.

Зачастую в документации о закупке могут необоснованно завышаться технические требования к закупаемой продукции с указанием специфических (или избыточных) особенностей, присущих только конкретному виду иностранного оборудования. Заказчики продолжают смешивать лоты с российской и иностранной продукцией и обходят установленные преференции для отечественной продукции. При этом административная ответственность в виде штрафа или дисквалификации редко применяется и должностного лица заказчика не останавливает совершать злоупотребления.

В таких условиях не то что выиграть, даже подать заявку на участие в конкурсе сложно. Пример из практики: Российский онкологический центр имени Блохина в конце 2018 года опубликовал ряд аукционов на поставку медицинского оборудования общей суммой более 1 млрд руб. Заказчик предпринял попытку осуществления смешанной закупки оборудования как российского, так и импортного производства. Действия заказчика обжаловались в ФАС более 10 раз, что повлекло со стороны заказчика внесение более 10 раз незначительных изменений в документацию. После этого заказчик заново продолжил торги, заточенные на импортное оборудование. 
2. У контрольных органов нет необходимого количества сотрудников, чтобы физически рассматривать на должном уровне жалобы. Мало того, спорные решения территориальных управлений не всегда может отменить центральный аппарат ФАС России.

Указанная ситуация не позволяет оперативно отменять недобросовестные закупки, которые прямо могут противоречить государственной политике в сфере импортозамещения. При этом действующим законодательством применение каких-либо значимых санкции кзаказчику не предусмотрено. Эту ситуацию необходимо исправлять.

3. Российские производители не знают объемы товаров, которые планируют закупить заказчики в течение предстоящего года. Поэтому невозможно планировать производство.

Функционал единой информационной системы в сфере закупок не позволяет одним кликом выгружать информацию о товарной номенклатуре, закупаемой заказчиками Российской Федерации.

4. Короткие сроки подачи заявок и исполнения контрактов не позволяют российским производителям активно поставлять свою продукцию.

При текущей ситуации закупается имеющаяся на складах иностранная продукция. Узаказчиков нет мотивации на постоянной основе взаимодействовать с российскими поставщиками при формировании технических заданий. Каким-либо нормативным актом не установлена обязанность такого взаимодействия.

5. Государственный каталог объектов закупок не работает на отстаивание интересов отечественной промышленности.

Текущая практика описания товаров (работ, услуг), включаемых в Каталог, не учитывает характеристики отечественной продукции (оператор Минфин России). Минпромторг России не имеет прямых полномочий влиять на подготовку описаний товаров (работ, услуг). Конечные решения о том, какие характеристики включаются в Каталог, принимаются юристами и финансистами, а не отраслевыми экспертами.

Очевидно, что Каталог не может формироваться без профессионалов своего дела, которые годами работают в отечественной промышленности.

6. Под видом закупки услуг и работ поставляется иностранная продукция при отсутствии каких-либо законодательных запретов.

Рынок закупок услуг и работ превышает объемы контрактации товаров. Очевидно, что заказчики через закупки услуг и работ обходят установленные преференции при закупках самих товаров. Тем сам саботируется проводимая государственная политика в сфере импортозамещения, что не позволяет исключить или уменьшить зависимость рынка от иностранных товаров.

7. На текущий момент отсутствуют механизмы, позволяющие стимулировать поставщиков товаров приобретать на этапе производства российские материалы, полуфабрикаты и сырье.

Это существенно ограничивает синергетический эффект кооперационного взаимодействия российских производителей. Возможно, стоит предоставить заказчикам полномочия устанавливать дополнительные требования к закупке отечественной ЭКБ при поставках конечных товаров.

8. Подавляющее число закупок происходит без авансирования контрактов, что выгодно крупным иностранным компаниям, имеющим доступ к дешевому кредитованию на международных рынках капитала.

Компании ОПК не могут привлекать необходимые кредитные средства на сопоставимых условиях, поэтому они поддерживают предложение Минэкономразвития России по авансированию закупок, направленных на импортозамещение при реализации национальных проектов (письмо Минэкономразвития России от 30 мая 2019 года № 17375-АТ / Д28и).

Обозначенные выше проблемы закупок свидетельствуют о том, что существующие механизмы поддержки отечественных производителей в сфере закупок фактически не работают. Государственный бюджет продолжает кормить другие страны. Для ОПК 2019 год в этой части прошел, так как многие заказчики уже провели все закупки, законтрактовав поставку иностранной продукции, используя различные уловки

Считаем необходимым и важным исправить эту ситуацию до масштабной реализации национальных проектов, иначе они не смогут стимулировать модернизацию российской промышленности.

Рассмотрим предложения отраслевого сообщества, которые могут переломить сложившуюся практику, идущую наперекор целям государственной политики по диверсификации и импортозамещению:

- Установить для заказчиков квоту по закупке российских товаров, включая закупку отечественных товаров у ОПК. Мера смелая, но вынужденная, иначе бюджетные деньги и в последующие годы пройдут мимо отечественных предприятий и ОПК.

- Наделить полномочиями Правительственную комиссию по импортозамещению отменять закупки при несоблюдении заказчиками политики импортозамещения 
- Предоставить центральному аппарату ФАС России возможность пересматривать решения территориальных органов при крупных закупках (по аналогии с судебной системой). Это позволит быстро влиять на закупки, а не проходить долгие судебные процедуры.

- Предоставить российским поставщикам полный доступ к информации о закупках на предстоящий год. Для этих целей доработать единую информационную систему в сфере закупок. Нельзя скрывать закупки от собственной промышленности.

- Наделить Минпромторг России реальными полномочиями по формированию описания промышленных товаров (работ, услуг), включаемых в Государственный каталог объектов закупок. Это позволит максимально учитывать интересы российской промышленности

- Определить актом правительства случаи обязательного авансирования государственных контрактов в размере не менее 50\% при реализации проектов в сфере импортозамещения

- Установить ограничения по использованию иностранных товаров при выполнении работ (оказания услуг)

- Проработать механизм, позволяющий стимулировать поставщиков приобретать российские материалы, полуфабрикаты и сырье при производстве товаров, поставляемых в государственные закупки. Предлагаем в качестве пилотного проекта апробировать такой подход на ЭКБ.

Проработка и продвижение указанных выше предложений активно ведется в рамках работы Экспертного совета при профильном комитете Госдумы, возглавляемом индустриальным директором РЭК Сахненко С. С., при активном участии координационного совета Союза машиностроителей России. Проект постановления по авансированию и по квотам уже разработаны и направлены на согласование в ФОИВы. Разработан и реализуется план действий, направленный на поддержку отечественных производителей радиоэлектронной продукции. План предполагает изменения в 44-Ф3, 223-Ф3, 147-Ф3 и соответствующих подзаконных актах к ним. Продвижение нормативно-правовых инициатив, нацеленных на устранение недобросовестных практик при осуществлении закупок радиоэлектронной продукции, будет стимулировать развитие отечественных производств в сегменте гражданской продукции. Для этого необходима отраслевая консолидация вокруг упомянутых в статье экспертных площадок и эффективные действия вместе с ФОИВами, направленные на реализацию плана мероприятий, реализующих отраслевую стратегию развития.

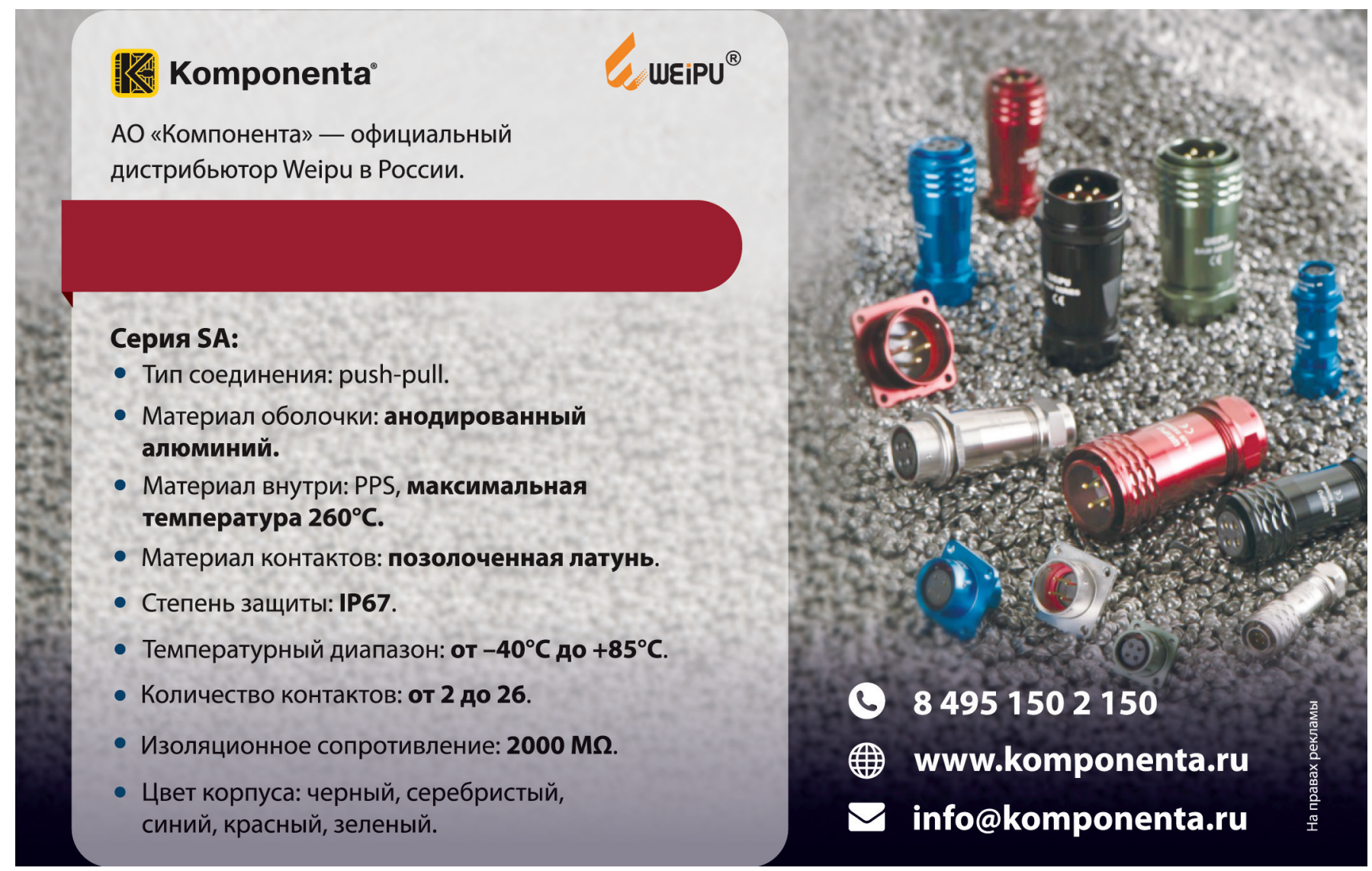

